\title{
2
}

\section{Flexibility, Possibility and the Paradoxes of the Present: Tongan Youth Moving into the Future}

\author{
Mary K Good
}

\section{Introduction}

The increasing interest in, and pressures of, seeking employment for youth in Tonga have apparently become so widespread as to be worthy of satire. In mid-November 2016, the group Facebook page 'Must Be Tongan', which regularly hosted discussions about Tongan identity and posted humorous photos and memes about Tongan life, posted a video of a short satirical job interview. In the comedic clip, an 'employer' reviews the resume of a prospective 'job seeker', given the name 'Sione Mango'. ${ }^{1}$ Symbolic cues send up the stark differences between the two young men-the employer sits behind his shiny Mac computer wearing a closefitting black blazer and Clark Kent, hipster-style glasses and speaking clearly yet quickly, while his interviewee sits across from him, eyes cast down in the traditional gaze of humility, with a youthful beanie pulled low on his head and slowly mumbling his answers. It seems unlikely that

1 Across the Facebook and YouTube platforms, as well as among youth I knew in Tonga, the character of 'Sione Mango' is often employed as a kind of humorous, none-too-intelligent Tongan everyman. The surname 'Mango' is considered particularly funny because of its association with the fruit, and it is not a real Tongan surname. 
the poor job seeker will secure employment. The plot twists, however, when the employer says, 'Wait! Your name is Sione Mango? Where are you from? Who is your family?' The two young men quickly discover a distant connection between relatives. 'Well, your resume isn't so great, but you're a Mango. Come in tomorrow, we'll find you work!' The employer says, and the clip concludes.

Within just two hours of posting, this clip had been viewed over 2,700 times and had received 318 likes. One year later, it had around 80,000 views, 3,000 likes, 715 shares and 428 comments-which is perhaps even more surprising when considering that about 110,000 people live in the Pacific Island nation of Tonga, although many other people claiming Tongan heritage live in diasporic communities elsewhere.

The clip's humour relies on the apparent ubiquity of this experience and the ways that it affects youth who are currently seeking jobs. Its ability to collect likes and comments, with many laughingly narrating similar experiences, revolves around a sense of discomfort among youth in regard to the practices of relying on family connections to find employment. The comments also reveal an emerging understanding of the desirability of formal employment and the perceived stress of finding a job. It is notable that the characters in the clip are young; it would not have seemed as funny to the many Tongan commenters if the actors were older adults, because older adults often expect and rely on their familial ties to create the 'pathway', or hala, to success in all areas of life. This short clip encapsulates one of the paradoxes of seeking employment among the youth in Tonga with whom I work: the growing desire to find a good job based on one's individual qualifications and without the help of family connections, but the stronger moral obligation to find a job in any way possible to help one's family. For many Tongan youth, the drive for individual 'empowerment' and success is intricately entangled with notions of obligation to care for others within the circle of social relations (see Cole 2004; Cole \& Cole 2007; Durham 2007).

While many people in Tonga have historically been involved in formal employment of some sort, only in the past few decades has professional waged work become increasingly important as the country moves from a primarily subsistence-based economy to a more global, capitalistbased system. At the same time, however, the path from school into the workforce is not a foregone conclusion for youth and, in fact, many families rely on at least some of their children staying out of the formal 
employment system to help maintain the household and their family's land for crops. Still, the growing trend towards formal employment has led to new opportunities and aspirations for young people as they move from their school years into the more uncertain and liminal status prior to full adulthood. New pressures have also accompanied these new possibilities. Tongan youth on the outer island of 'Eua felt a keen sense of obligation to find a job and to help with the mounting everyday expenses at home, but the pressure to seek employment often outstrips the jobs that are available. In my research and in discussions with aid organisations in Tonga, I found that youth reported feelings of 'stress' about finding work as well as a moral responsibility to work. Older adults highlighted this social change to me as well, noting that it seemed as if more young people wanted to work outside the traditional home-bound labour of farming, fishing or producing culturally significant handicrafts. It appears that a re-evaluation of youth is happening, moving from being defined by relative freedom from responsibility to being assessed for the value of possible paid and productive labour. Moreover, government mission statements and non-government organisation workshops project a spirit of obligation to the nation and its cultural heritage, while simultaneously espousing neoliberal visions of individually driven 'entrepreneurial' and 'proactive' youth that seem in direct competition with traditional Tongan ways (anga faka-Tonga). Tongan youth seeking employment, or dealing with the realities of unemployment and underemployment, present an intriguing case through which to understand the ways in which shifting roles and responsibilities on multiple levels within a local context do not always map neatly onto neoliberal notions of individual 'empowerment' and independence.

This chapter investigates the movements of youth on the island of 'Eua in Tonga as they attempt to find work and reconcile their goals and ideals with reality. In doing so, I also examine the ways in which discourses about youth and, in particular, youth unemployment become entangled with discourses of neoliberal modernity in Tonga. 'Euan youth in a variety of employment situations must all struggle to make sense of the disjuncture between their imagined possibilities for work, their sense of moral obligation to work and the actual choices that work presents. 


\section{Methods}

My research on youth employment and unemployment on the island of 'Eua in Tonga grew out of a previous project focusing on how the processes of global modernity affected youths' ideas about morality and family responsibility as they engaged with new forms of digital media (Good 2012). In 2008-09, as part of my larger fieldwork, I volunteered at 'Eua High School and worked as a volunteer with the 'Eua Youth Congress, the regional branch of a nation-wide youth organisation. I also conducted participant observation with several social groups of youth across the island, participating in a range of daily life activities for young people, such as attending church youth groups, helping with chores and simply hanging out. Along with this, I conducted approximately 50 longform interviews with students from 'Eua High School, as well as youth who had dropped out of school and those who had graduated from high school. The interviews that I conducted covered several topics, including those related to family responsibility and to youths' wishes for the future. In doing so, I collected initial observations about the employment prospects and career aspirations for young people.

Then, in 2016, I began a new research project that was specifically directed at examining unemployment, employment and entrepreneurship—-topics that had begun to emerge in the conversations of my research participants and that garnered considerable attention among local media sources, government ministries and youth organisations. I discussed employment opportunities and experiences with employers and hopeful youth employees in Nuku'alofa, the nation's capital, as well as on the island of 'Eua. While on 'Eua, I conducted interviews with youth who were seeking work, as well as those in a variety of positions, including teachers, military personnel, utility operators, petrol station and grocery store attendants, and workers in the tourism industry. My previous interviews in 2008-09 were particularly interesting to revisit, with some of the same research participants who for the most part now held vastly different positions from those we had discussed. Finally, I had the opportunity to 'job shadow' a few research participants as they went about their work day. These methods allowed me to observe the ways that an increased attention to formal employment for youth had affected the lives of youth in this specific context. 


\section{A Neoliberal Monarchy in Transformation}

The sociopolitical context of contemporary Tongan life provides a perspective of youth futures that emerges as intriguing and unique, even within the Pacific region. Current economic development and its social effects have led the nation of Tonga into what could be described as a 'neoliberal monarchy'. ${ }^{2}$ Shedding light on various specific manifestations of neoliberal capitalism and its social reverberations allows us to better understand the complexities of recent economic and cultural transformations around the world, while avoiding the trap of inaccurately conceiving neoliberalism as a homogenous, and homogenising, process (Freeman 2014; Harvey 2005).

I characterise Tonga as a neoliberal monarchy because of the ways in which the nation attempts, and at times succeeds, to embrace elements of neoliberal capitalist currents that circulate around the world in a way that is distinctly influenced by its particular forms of government and cultural traditions. The privatisation and deregulation of markets, a decoupling of social services from public institutions and a shift to responsibilisation of individuals for their own financial successes have been identified as some of the standard hallmarks of neoliberalism since the late 1970s and early 1980s (Harvey 2005, p. 3; Trnka \& Trundle 2017). Over the past few decades, aspects of Tonga's economy and society have followed suit. Beginning in the late 1980s, utility services, including electric power and communications (landline phones), were separated from government oversight and were privatised. Following this, changes in regulations opened the country to private multinational mobile phone companies and, later, to internet and satellite television providers. In the early 2000 s, the government of King George Tupou IV began to move towards significant changes in government that would allow a greater representation of the majority of the population and other transformations (Besnier 2011; Campbell 2008). Transnational aid organisations and foreign government assistance had long been a part of the Tongan social landscape, but, particularly following the political riots of 2006, programs for youth involving employment and entrepreneurship skills proliferated. Programs

2 I wish to thank Catherine Trundle and Susanna Trnka for their help in suggesting this label for my description of Tonga's entry into a locally specific form of neoliberalism. 
that were targeted at building various skills among youth reflected the discourses and central tenets of neoliberalism, which will be discussed in further detail below.

However, throughout the slow process of the development of this neoliberal, capitalist system, distinctive traits of the Tongan monarchic cultural tradition continued to hold considerable sway within mainstream discourse. Tongan people continue to uphold traditional values of respect (faka'apa'apa) that are rooted in a cultural and governmental system that characterises all Tongans as possible relatives and, more specifically, as siblings-thereby requiring care and generosity (Philips 2004). While popular support has seemingly grown for a more accountable and representative government, many Tongans who I know still have a sense of love and devotion towards the King and the royal family. Perhaps, most significantly, everyday social relations on the island of 'Eua still revolved around ideas of reciprocity and relations of exchange in concentric and overlapping networks of family, church affiliation and village membership that extended outward, even to island residence. Although privatisation and a gradual shift towards a capitalist economy was occurring on 'Eua and across Tonga more generally, kinship ties and other social relations of reciprocity remain critical to life. For these reasons, Tonga presents a unique case for examining the extent to which neoliberal values have affected people's lives. In particular, the growth of a neoliberal capitalist market in Tonga has motivated both the discourse regarding youth unemployment as a concept worthy of attention and the particular traits and experiences that youth have with regard to formal, waged labour.

\section{Youth, Flexibility, Mobility and Obedience}

In some notable ways, the socialisation of children throughout their years of schooling and growing up on 'Eua produces youth that mirror the qualities associated with an idealised neoliberal subject. However, paradoxically, these qualities have been cultivated in youth for certain reasons that do not necessarily coincide with those neoliberal values. Characteristics that are commonly associated with a 'neoliberal self' include flexibility and adaptability (Freeman 2014, p. 19), in which the subject becomes a collection of skills that can be added to and 'marketed' in specific ways, depending on the context (Gershon 2011, p. 539). Further, neoliberal subjects must be flexible and adaptable to new situations and 
demands of 'the marketplace', without any rigid reliance on the known ways of doing things, and they must be mobile enough to adapt to new places and new demands (Freeman 2014, p. 20). The neoliberal subject is ideally self-reflective and in control of himself or herself as well.

Tongan cultural notions of child development somewhat paradoxically follow similar guidelines, although they also diverge from the ideas of the neoliberal subject in important ways. Throughout childhood, the notion of unquestioning obedience to elders is reinforced both at home and at school (Morton 1996, pp. 91-96). However, a side effect of this constant emphasis on obedience (talangofua) that I observed among young children and youth on 'Eua was a heightened sense of flexibility and adaptability. Children learn from a young age that they do not have much control over their environments or over the expectations that adults have for them. They are simply taught to obey requests and to complete specific tasks without questioning the reasons behind them. Somewhat surprisingly, this leads to an attitude of considerable flexibility and adaptability to different situations as children grow older. As I observed youth at their jobs, it was fairly common for friends and relatives of the same age to stop by for a chat. In several instances, the young person who was working called on their friend to help with a task. Due to their socialisation involving help with whatever was requested, youth had an impressive ability to catch on to various tasks and complete them fairly quickly, with minimal supervision or instruction. It appeared that while obedience to orders might conflict with a spirit of neoliberal self-supervision and independence, the underlying flexibility and adaptability that it produced in this context helped youth become accustomed to the needs for these traits in their employment positions.

The expectations for and experiences of youth on 'Eua reflect a need for a certain type of nimble adaptability to a transforming world. However, rather than simply emphasising a flexibility in the mastering of multifaceted skills, the lived reality of these youth instead reveals a flexibility of aspirations and acceptance-making do with employment and living situations that perhaps do not take advantage of variety of skills that youth have developed. The paradox of the present for youth at this juncture in the development of Tonga's economy and its embrace of a locally particular neoliberalism is that, rather than an 'opening up' of opportunity or even a renewed emphasis on efficiency, rationality and goal-driven individualism paving the way forward, youth regard their 
futures as laden with new stress, competing responsibilities and ambiguous pathways that lie ahead. Youths' experiences show a mix of optimism, possibility and coming to terms with the paradoxes of the present.

Several large transnational NGOs have funded development programs that were targeted at youth, including a few entrepreneurship and smallbusiness management workshops. These programs, as one member of a youth organisation enthusiastically explained to me, 'help everyone! They help the youth, but also women, families, the village, at home ... it's good for everybody, if we can get them up and running!' As I talked to members of this organisation who had received a sizeable grant to promote organic farming among youth cooperatives, it became clear that the program was operationalised in a way that melded characteristically neoliberal discourses of youth 'empowerment', efficiency, rational decision-making and entrepreneurship with a separate discourse of relational thinking and care of others. Youth who participated in the program, according to another youth leader, would 'become their own advocates' and 'make their own pathway, have their own business'. The benefits of the program were simultaneously couched in language that made it clear that youth would be expected to share their profits to help their parents, families and extended kin. They would also share the responsibility of continuing the program by teaching others. As they learned the principles of making a business plan, keeping strict accounts and looking out for their own competitive business, emphasis was still placed on how this would help others in the youths' social worlds, extending to how to serve the economic needs of the nation as a whole.

As youth become involved in programs to develop skills or to seek employment in already-existing businesses, more youth begin to feel as if they must find a job, and the idea of youth as a carefree and relatively low-responsibility time of life begins to shift. The entry of youth into the developing workforce becomes spurred on by, but also sometimes thwarted by, the idea of a young person as the 'ideal worker' in Tonga. Youth are regarded as physically strong and capable of quick, energetic movement, unlike older adults who may feel both physically weaker and culturally constrained to project a sense of high-status, impassive stillness. As labourers, youth are valued for their image of obedience and their relatively low status in Tonga's highly stratified and hierarchical cultural order, meaning that few adults would have any qualms about 
giving them instructions. This can at times create a sense of conflict when youth are urged to make their own decisions and become 'proactive' in entrepreneurship and new work skills trainings.

Coming back to the initial opening story, another paradox of finding employment for Tongan youth revolves around the understanding of selfhood and relationality as they relate to the act of looking for work. The neoliberal discourses that dominate Tongan youth organisations and much of the education system have begun to stress the idea of empowerment and self-reliance in a way that is quite new for Tonga, in which traditional beliefs consider individuals embedded in networks of caring relatives to whom one calls on for help and is obligated to assist in turn. The idea of the 'neoliberal individual', however, focuses on one's ability to act in the interest of only oneself, without the help of, or the responsibility to, others. What has transpired, then, is that many young people espouse a desire to find work without relying on family connections for 'help' in securing a position; however, these goals often had to be abandoned, as people realised that this might be the only way that they could get work.

For example, a young woman named Malia told me the story of how she had prayed regularly for guidance in both seeking the right kind of work and then finding a job in that field. She finally had found her 'calling' in agribusiness and she knew that she could possibly have used family and church connections to help her, but she wanted to find a job 'on her own, with the skills she had learned in college'. After several months of being turned down for jobs, however, she finally told an uncle her troubles and had a secure position at a supply outlet for government agricultural works in about a week.

\section{Dreams for the Future}

As is the case in the United States, Australia and New Zealand, secondary school-aged youth in Tonga were socialised to think about their future and about what kinds of dreams they had for career aspirations. However, realistic pathways to those dreams did not always exist for Tongan children, and the idea of dreams for the future were also cast in terms of family responsibility and family conversations. The ability to have a personal dream about a career goal was often tempered by discussions that youth were involved in with other members of their family regarding what their role would be, whether to stay home to care for parents or 
whether to enter a particular profession for the good of the family, such as a nurse who might be able to help care for elderly family members at home. Goals also varied widely based in part on the resources of the family, or on what might be regarded as an emergent socioeconomic class position. Connections to family in diasporic communities and access to educational opportunities made a difference in the ways that youth thought about possible options for either career training or eventual employment (Lee 2003; Lee \& Francis 2009).

As I discussed employment and unemployment with youth and adults in 'Eua and through my observations, it became clear that although youth feel increasing pressure to find work after they have completed their schooling, it is still not the case that a specific narrative of 'school to work transition' exists. In other words, it is not taken for granted that one will immediately find a job after secondary school, or that one will automatically enter some sort of tertiary program or even that finding a job immediately following upper-level education would be possible. Families on 'Eua still relied on young people in the family to help with the labour of farming, fishing and other self-provisioning activities-and when formal waged employment was unavailable, many youth spent their time working at home instead, altering their visions of what the future might hold.

\section{Possibilities and Paradoxes: Three Case Studies}

To show some of the ways in which opportunities for employment and pathways to work unfold for youth on 'Eua, I will employ three specific case studies of young people who I have come to know well over my longterm fieldwork. Each of their experiences shows the ways that flexibility, mobility and adaptability become critical to gaining employment on 'Eua. Moreover, their stories highlight the ways that youth, even when employed, still occupy a liminal position in Tongan culture, with considerably more responsibility and autonomy than children, but are still dependent in some ways on older adults. 


\section{Tomasi}

The ways in which a sense of moral obligation to help one's family financially and how mobility and flexibility play into employment opportunities for youth are well illustrated in the story of Tomasi's path to becoming an elementary school teacher. Cheerful and always incredibly helpful to others, 21-year-old Tomasi was also an avid user of Facebook and we had kept in fairly regular contact online in the years since my last visit to 'Eua. He invited me to visit his classroom at the elementary school, which he had meticulously decorated with colourful learning charts and optimistic slogans. Tomasi seemed to enjoy his work as a schoolteacher and so I was surprised when he told me that he had not always intended to go into education. Tomasi's story lends insight into the distributed agency of career decisions for youth on 'Eua and into the many other perspectives of the possibilities and motivations for finding work.

Tomasi told me that his tight-knit family often discussed plans for the future as part of their nightly prayer time. Many families on 'Eua came together in the evening to read from the Bible, pray together and discuss important events or deliver counselling and advice ('akonaki) to the children. Tomasi said that he had always wanted to become a nurse and that this had been in keeping with what his family had discussed. However, at the time that he graduated from high school, the national nursing education program required all applicants be 18 years or older. Tomasi had managed to pass through his education with flying colours quickly, and so he had graduated at age 17. Rather than wait another year to apply for the nursing program, Tomasi and his family decided that he should apply to the Tonga Teachers' Training College-and he was accepted. Both nursing and teaching are considered quintessentially stable and respectable civil service positions in Tonga. Although it seemed surprising to me that Tomasi would so easily make the switch between two quite different career aspirations, he said that he became quickly happy with his decision because it would allow him to learn new skills and find a job through which he could begin to earn money for his family.

Tomasi confessed to me that he was shy and intimidated in the first year of his teacher education, being the youngest student and having come to study from 'Eua, an island whose inhabitants are often stereotyped as being less attuned to cultural standards than other Tongans. Tomasi's experience also reflected the need for adaptability to new situations, as well as flexibility and mobility. Tomasi moved from his home island of 'Eua 
to the main island of Tongatapu to attend the teacher training. While on Tongatapu, he said that he moved between multiple sets of relatives over the period of his training. It was fairly common for children and young adults from 'Eua to periodically visit relatives on Tongatapu or to be sent there for longer periods of time for school or work. The relatives were expected to take the children in as part of the understanding of family obligations among extended kin, yet it seemed that this could sometimes stretch social relations and food stores to near-breaking point. For Tomasi, living with extended family on Tongatapu was further complicated due to the fact that his nuclear family had converted to the Mormon faith, while many of his extended relatives remained affiliates of more mainstream Christian churches. This led to tension and disagreements between the young man and his relatives, which he said occasionally caused him to doubt whether he would be able to complete his studies. However, he finally finished the teacher training course and was delighted to discover that he was near the top of his class, which would guarantee him a teaching placement. Tomasi was able to secure a position in an elementary school on 'Eua, so he moved back into the home of his parents.

As he told me the story of his training and employment, Tomasi frequently repeated the idea that his efforts to achieve his goals were not only for himself, but for the good of his entire family. He regarded his success in the teacher training program as a reflection of his commitment to his family and as a way of showing his love for his parents. He understood this as something of a reciprocal process; in Tomasi's mind, his success and eventual employment was a way that he could return some of the love and generosity with which his parents had cared for him. Tomasi also told me that when he received his pay cheque, he immediately turned it over to his parents to contribute to the upkeep of the entire family. He highlighted that this would change when he eventually got married, for then his responsibility would shift towards providing for his own wife and children - though he was still offering help to his parents and siblings when he could.

Tomasi and I also talked about the ways that his Mormon faith had influenced his decisions to work and how it might affect his future. His faith and religious beliefs guided him during times of difficulty in his studies, Tomasi told me, and the beliefs of the Mormon Church seemed to influence his decisions to contribute his earnings to his nuclear family. As a young man in the Mormon Church, Tomasi was eligible to apply for a two-year international missionary post. Many Mormons do their 
mission service in their late teens or early 20 s, but Tomasi delayed his missionary service for a few years to begin his career as a teacher. At the time we talked, Tomasi had decided that he would apply for a mission post soon, within the next few years, and he was unsure about whether he would return to teaching or not after his service. Although he had devoted considerable time and energy into his training to become a teacher, Tomasi told me that, following his service, other opportunities might present themselves and he might consider those-or maybe he would even apply for nursing school. Rather than committing to a career for life, as it seemed many people of older generations had done after training to be teachers or other civil service positions, Tomasi seemed more inclined to explore his options, as did many other Tongan youth with whom I spoke. Tomasi's life as a young, emerging adult had already taken a path towards the future, which involved moving for career training, work in a field that was different from his original goals and the possibility of changing careers later on—all influenced by a deeply held religious conviction.

\section{Lesieli}

When I arrived in the capital city of Tonga for research in July 2016 and met with friends at the main office of the Tonga Youth Congress, I was surprised to learn that a young woman who had been a former student in my English class at 'Eua High School had now become the office manager for the 'Eua Youth Congress branch. Lesieli, now in her early 20 s, had come to this position through a roundabout series of paths, but she had become quite passionate about her work over the course of her first year with the youth organisation. The story of Lesieli's employment with the 'Eua Youth Congress highlights the ways in which new possibilities for youth employment have emerged, the adaptability of youth to new opportunities that are presented to them and some of the modes in which longstanding gender ideologies might still constrain who gets which jobs.

When I arrived on the island of 'Eua, I was able to find Lesieli and arrange an interview with her. We met in the 'Eua Youth Congress (EYC) office, in a relatively new meeting hall building that had been divided into offices with unpainted plywood partitions. The EYC offices shared the building with a Vanilla Farmers' Cooperative and, as we chatted, the smell of thousands of vanilla pods curing in the warm sun outside wafted pleasantly through the building. Despite the unfinished appearance of the building, Lesieli herself was dressed in a neat, professional skirt and blouse and her cheery smile was accented with bright pink lipstick. Lesieli's dress 
and mannerisms symbolically reflected how seriously she took her position as a paid office employee in contrast to the volunteers, who filtered in and out of the building in more casual attire. Later, we took a tour through the farm structures behind the office where the EYC's equipment for their organic coconut oil-pressing project was stored. Lesieli had been hired in part because of a major grant that the Tonga National Youth Congress had received to partner with a transnational aid organisation in developing new small-business opportunities related to agriculture that would specifically benefit rural women and youth. Over the course of our conversation, the program consultant from the aid organisation stopped by to review the project with Lesieli and joined our discussion.

Lesieli had graduated from 'Eua High School and then went on to study for a tertiary certificate at a vocational school in Nuku'alofa. She recounted how she had returned to 'Eua after her studies and quickly tired of 'just sitting around, doing nothing'. Few employment opportunities were to be found near her village, she said, so she spent her time helping her family with the daily household chores and visiting her friends. One day, an old schoolmate asked Lesieli to join her in volunteering for the EYC. The young woman wanted to participate in the club but was too shy to go by herself because the group was typically dominated by young men, some of whom came from other villages. Lesieli went with her friend to volunteer for a trash clean-up at one of the nearby beaches and found that she enjoyed working with the group. She continued to participate in meetings and events as a volunteer. When the project to produce coconut oil began to grow, she was offered a formal position as office manager with a small salary_-and she had been working at the EYC ever since.

Lesieli enjoyed her job and discussed her passion for working with youth and helping to combat the issue of unemployment that was frequently discussed among youth organisation workers and in the mainstream Tongan media. She also seemed quite acutely aware of the ways that the process of seeking work affected young men and women differently. 'We haven't been able to get many women to participate', she said, 'because they feel ashamed/embarrassed $[m \bar{a}]$. There are too many young men that work, and the women get embarrassed'. The traditional Tongan cultural value of $m \bar{a}$ (shame or embarrassment) is a form of moral sentiment (Mattingly 2013; Throop 2012, p. 159) inculcated in young people to show respect for elders and for upholding particular social relations within the Tongan cultural context. Particularly for young women, $m \bar{a}$ signals their awareness of cultural standards prohibiting young women from openly socialising with young men whom they do not know, which 
would be interpreted as possibly signalling romantic or sexual interest. Feelings of $m \bar{a}$ are often performed by young women in the appearance of shyness, in avoiding eye contact, hiding or showing physical reluctance to take part in activities, and by pulling sarongs, hoods or other clothing over their faces. More broadly, showing signs of shyness or embarrassment was often interpreted positively by older adults as a sign that young women knew the cultural values of the demure, 'pure' femininity that they were meant to uphold. However, in the case of young women seeking employment, the socialisation into this particular moral sentiment poses a paradox: showing oneself to be $m \bar{a}$ in the presence of strangers might reflect a certain type of respect for traditional Tongan values, yet it also prevents young people from participating in forms of interactions that are necessary for many types of employment. The moral sentiment of $m \bar{a}$ had kept Lesieli and her friend (as well as many other young women) away from volunteering for the EYC at first, Lesieli told me, but they had overcome their shyness and 'acted bravely', according to her, so that they could participate.

As she described her current position, Lesieli discussed the ways that it had been difficult to find young women to work in the coconut oil program because of their shyness. She also attributed some of this shyness to the types of work that the project required. The coconut oil project required participants to gather coconuts from their own farmland and to bring them into the youth centre, where they were then processed and pressed for oil. Although both men and women perform farm work on 'Eua, gender ideologies associate this kind of outdoor, dirty, physical labour with men and masculinity, whereas women's work is regarded as light, clean and located in the home (Morton 1996, pp. 100-101). Because of these longstanding ideologies, attracting young women to the coconut oil program proved to be difficult. However, Lesieli and the program consultant who chatted with us claimed that there was one thing that helped to overcome young women's reluctance and $m \bar{a}$ regarding the program: income. The women told me that once other young women realised that they could be paid quite well for their efforts to bring in coconuts and, sometimes, to help with processing the coconuts into oil, they became more interested and less embarrassed. Lesieli also mentioned that the organisation had done some work to promote the idea of women-only teams working together at the same time, but that this was still in development. 
It was clear that Lesieli enjoyed the work that she had found with the EYC and the opportunities that it provided for socialising with other young people. In contrast to the other youth that I spoke with about employment, Lesieli did not emphasise the fact that her work helped her family through her financial contributions; however, Lesieli did mention that she was happy to be working in a way that provided youth with support. Throughout the interview, she returned to the idea of working with youth as a means of helping her community and, in a way, fulfilling her culturally understood responsibility towards assisting others (fai fatongia, fe'tokoni'aki).

Towards the end of our conversation, it became clear that while Lesieli enjoyed her work and hoped to continue working with youth into the future, the position itself was not totally secure. After we had talked for a while inside the office, Lesieli, the program consultant and I took a walk through the drying vanilla and into the coconut-processing sheds behind the offices. Here we saw that the processing equipment had become dusty and dirty through lack of use, covered in cobwebs and other farming equipment. The two women told me that the program had been a great success in recruiting young people to bring in coconuts, but that they were having difficulties in establishing a market base and encouraging local consumers to purchase the oil products for cooking or the soap products for personal use rather than buying the imported vegetable oil and soaps from the shops. Some of the products had been sold successfully in the local eco-lodges, but the tourism trade could not fully support the production. Lesieli and the program consultant said that the Tonga Youth Congress had been exploring export markets, but that it had yet to find a viable solution. Part of the problem, they said, was that the production volume had been too high for local markets, but that it was insufficient for export markets and that storage of products to build up a base had also proven difficult. Lesieli's job was partially funded through the grant and, if the project did not continue, her position might be eliminated. This was a fairly common issue among the young people who I talked to that had found work with non-profit organisations on 'Eua and on the main island of Tongatapu - often the work was quite satisfying and both financially and morally fulfilling for youth, but positions could be temporary or precariously dependent on continued aid funding. Lesieli remained optimistic about her future prospects but, in a typical fashion for youth on 'Eua that I had encountered before, she shrugged her shoulders 
and laughingly said, 'But who knows, I might go back home [to resume housework] or get married', which she saw as the effective end to her career with youth organisations.

\section{Sita}

Finally, the early employment pathways of a young woman named Sita reflect the uncertainty, mobility, flexibility and moral responsibility of Tongan youth as they move from family dependents to a role with greater perceived obligation to assist with family expenses. Sita was a 21 -year-old young woman who lived with her parents and a large family of siblings, in-laws, nieces and nephews in the centre of the biggest town on 'Eua. Sita told me a bit about her employment history and the ways that she and her family worked together to make economic decisions on a sunny afternoon as she rested between her morning shift as a babysitter and her evening shift at the island's bakery. Sita had pieced together a number of different work opportunities on the island of 'Eua and had secured regular employment in a migrant work scheme abroad without significant education or special skills, reflecting the ways in which youth on 'Eua cultivate 'flexibility' and accept change as part of life. The ability of Sita and others I knew to adapt to new opportunities and work requirements as they arose was particularly remarkable for their casual acceptance of these changes, so the flexibility seemed almost commonplace rather than a new or imposed aspect of a contemporary neoliberal era.

Although Sita told me that she was never a good student and laughingly claimed that she was only interested in English so that she could watch foreign movies, she and her sisters had a fairly high degree of English fluency and practised their spoken English as often as they could with me, tourists on the island or with each other. Their older siblings, as well as their aunts and uncles living nearby, had nearly all spent some time overseas in New Zealand, Australia or the United States, and the younger sisters would often talk about the stories that their older relatives had told them about living and working abroad.

Sita had left school after failing her Form Five certificate exam three times (the maximum number of times that students were allowed to sit for the exam). Following that, she began helping one of her older sisters in her work of cleaning up the Methodist church in town and taking care of the minister's home. When her sister got married and had children of her own, Sita 'inherited' her sister's job as a housekeeper. Later, Sita found 
work as a babysitter, which was a relatively new type of waged work on 'Eua. Many people believed that families should be able to care for their own children or that they should rely on the help of extended kin, so paying for childcare — or being paid to care for others' children — seemed unusual at first to many people on 'Eua. Sita came across her babysitting job through a relative's co-worker. Over the years, Sita worked at many temporary jobs in housekeeping and other odd jobs that are traditionally done by young women. She told me that she felt it was important for her to find work so that she could contribute financially to her family. Sitas mother had a chronic illness and her father and brothers provided for the family by working on the farm and fishing. She saw her contributions as one of the few ways that the family could earn money apart from relying on relatives' occasional overseas remittances.

In 2015, Sita was offered the opportunity to go overseas as part of a group of women who would travel together to work as fruit-picking and packing labour in Australia. Sita discussed the opportunity with her family and they decided together that she should go. The overseas job represented both a chance to make significantly more money than she was able to in her cleaning or babysitting positions around 'Eua, and she was also excited by the idea of travelling to new places and meeting new friends. After completing a successful six-month trip, Sita returned to 'Eua and was already submitting her paperwork to go again the following year. She had made some close friends and said that she enjoyed the work, which she described as easy, if a little monotonous. Sita had also quickly found another job while back at home on 'Eua. Again, through friends of relatives, she had heard about an opening at the island's only bakery. At first, she was a little hesitant about the job because it required working at night with a small group of young men who she did not know. However, after once again discussing her options with her parents and family, she decided to give it a try. Later in the week, I visited Sita at the bakery with a friend. After she had given us a free loaf of bread to snack on, she showed us around and described the process of producing the industrial loaves. She was happy to provide for her family with her job and was especially happy about the added bonus of discounted bread, which was a rare treat for most families on the island. Sita's feelings of moral responsibility towards helping her family financially, her willingness to listen to her parents' advice and follow their suggestions about work and her industriousness in taking the positions that were available to her seemed to indicate the ways 
that youth on 'Eua are socialised from a young age into habits of flexibility and mobility, which are qualities prized by both Tongan adults seeking obedience as well as a neoliberal order.

\section{Flexibility, Mobility and the Future}

The case studies of Tomasi, Lesieli and Sita help to illustrate some common themes that I found throughout my interviews and observations with working youth on the island of 'Eua (Good 2012). While the entire nation of Tonga could be described as an economic system in development, the relatively rural island of 'Eua presents some interesting challenges that are specific to its own context. The people of 'Eua recognise an increasing need for cash, not only to pay the utility bills and school fees that they have become accustomed to over the years, but also to provide for new expenses, such as packaged food from the store to supplement their self-provisioning, fuel for the cars that they have grown to rely on and internet and mobile phone service. The availability of jobs has not grown at the same pace as the need for cash, which relates to the first of the common themes represented in the case studies. As in the case of Lesieli, youth on 'Eua who would like formal employment often found a lack of jobs that matched their credentials or desired goals for their professional futures. As both Lesieli and Sita did, youth on 'Eua must thus accept the jobs available to them if they wanted to work. As mentioned above, youth were often encouraged at school and by their parents and relatives to cultivate specific dreams for particular professions and visions of the future-but, in reality, they often had to settle for any position available, at least for the time being. In contrast to the experiences of young men in India, as described by Craig Jeffrey (2010a, 2010b), who decided to take additional university degrees rather than become unemployed or work in a less-desirable position, or the experiences of young men in Ethiopia who languished in a state of unemployment while waiting for a respectable job (Mains 2007), the youth who I talked with about their work and who I observed in their jobs were willing to accept a variety of positions because of the moral responsibility to contribute to the family's resources. In Tomasi's case, he was fortunate to find a position in an 'Euan school that fit with his training and amended, yet intended, goals. However, not all schoolteachers are able to find work in the place and at the level they want, and many must decide between working as a teacher in another 
location across Tonga or staying with their families at home. Youth on 'Eua had to maintain a level of flexibility and acceptance in securing employment if they wished to work at all.

Along with the flexibility and acceptance of types of work available, I was also struck by the ways that many youth acquired formal waged employment through relatively informal channels. Both Lesieli and Sita found jobs through social connections and did not complete formal application procedures, which highlights the paradox discussed above regarding the ambivalence that youth feel towards relying on networks for resources, including jobs. Tomasi was able to acquire his position because of his strong performance within the teacher training program, which could indicate that more established positions like those in civil service might require a more formal type of application process. However, Tomasi said that he did not need to complete interviews or additional steps to acquire his position because his class standing in the program guaranteed him employment.

Finally, the requirements for mobility and adaptability to new environments can be observed to some extent across each of these case studies, particularly for Tomasi and Sita. Tomasi's job training required him to leave his home and stay with relatives for the duration of the program, and his placement might have required further mobility. He also expects to move internationally for his mission service and was uncertain as to whether he would find a position on 'Eua when he came back. Likewise, Sita had taken jobs in several different villages across the island of 'Eua before embarking on a pattern of circular migration between Tonga and Australia to participate in seasonal labour, which could provide better wages than local employment. The youth presented here in these case studies, as well as nearly all my other research participants, also expected that they might move away from their home village and birth family eventually for marriage, work or both. The circumstances that have led youth to an increasing focus on finding employment have also led them to expectations of increased mobility and uncertainty for the future, even as they exhibit considerable adaptability to these changes. 


\section{Conclusion}

In the last few decades, Tonga has self-consciously constructed itself as a globally connected nation, enacting classic neoliberal policies including the deregulation and privatisation of services that are formerly provided by the government and opening up to transnational corporations with the products and marketing budgets to establish a strong presence in the economy and in the minds of youth. The government's latest strategic development plans also emphasise 'flexibility', 'strategising for success' and 'more modern and progressive skills'-hallmarks of the neoliberal efficient and rational individual. Shifts in government on a broader scale that cede some of the powers of the monarchy to a more representative and democratic parliament also reflect social transformations that are underway. Within this context, government ministries and non-profit, non-government organisations alike have begun to produce a widely circulating discourse of youth unemployment that is accompanied by new programs and workshops that aim to reduce this 'problem'.

Young people on the outer island of 'Eua felt an increased pressure to find formal employment, but they confronted significant challenges in finding work. Focusing on job-seeking youth in a context of uneven economic development and rapidly changing discourses regarding the place of youth such as can be seen in Tonga can help to provide a finer degree of nuance in understanding the processes that are associated with the idea of neoliberalism. The case studies presented here highlight the cultural specificity of the projects of neoliberal capitalism and the ways in which social transformation does not always occur in a cohesive, homogenising way. Flexible and adaptable, yet eschewing, individualistic models of agency-and driven by perceived moral responsibility to family - the 'Euan youth who discussed their lives with me presented complex portraits of a Pacific present in which mobility and change were expected parts of life and the future seemed uncertain. For the youth on 'Eua, it seems quite likely that the future will continue to present both opportunities for new experiences and the pressures that come with new possibilities. 


\section{References}

Besnier, N 2011, On the edge of the global: Modern anxieties in a Pacific Island nation, Stanford University Press, Palo Alto, CA, doi.org/10.1017/S00104 17515000183

Campbell, I 2008, 'Across the threshold: Regime change and uncertainty in Tonga 2005-2007', The Journal of Pacific History, vol. 43, no. 1, pp. 95-109, doi.org/10.1080/00223340802054719

Cole, J 2004, 'Fresh contact in Tamatave, Madagascar: Sex, money, and intergenerational transformation', American Ethnologist, vol. 31, no. 4, pp. 573-588, doi.org/10.1525/ae.2004.31.4.573

Cole, J \& Cole, D 2007, Generations and globalization: Youth, age, and family in the new world economy, University of Indiana Press, Bloomington.

Durham, D 2007, 'Empowering youth: Making youth citizens in Botswana', in J Cole \& D Durham (eds), Generations and globalization: Youth, age, and family in the new world economy, Indiana University Press, Bloomington, pp. 102-131.

Freeman, C 2014, Entrepreneurial selves: Neoliberal respectability and the making of a Caribbean middle class, Duke University Press, Durham.

Gershon, I 2011, 'Neoliberal agency. Special section: Keywords', Current Anthropology, vol. 52, no. 4, pp. 537-555, doi.org/10.1086/660866

Good, M 2012, 'Modern moralities, moral modernities: Ambivalence and change among youth in Tonga', $\mathrm{PhD}$ thesis, University of Arizona, Arizona.

Harvey, D 2005, A brief history of neoliberalism, Oxford University Press, Oxford.

Jeffrey, C 2010a, Timepass: Youth, class, and the politics of waiting in India, Stanford University Press, Palo Alto, CA.

Jeffrey, C 2010b, 'Timepass: Youth, class, and time among unemployed young men in India', American Ethnologist, vol. 37, no. 3, pp. 465-481, doi.org/ $10.1111 /$ j.1548-1425.2010.01266.x

Lee, H 2003, Tongans overseas: Between two shores, University of Hawai'i Press, Honolulu.

Lee, H \& Francis, S (eds) 2009, Migration and transnationalism: Pacific perspectives, ANU Press, Canberra, doi.org/10.22459/MT.08.2009 
Mains, D 2007, 'Neoliberal times: Progress, boredom, and shame among young men in urban Ethiopia', American Ethnologist, vol. 34, no. 4, pp. 659-673, doi.org/10.1525/ae.2007.34.4.659

Mains, D 2012, Hope is cut: Youth, unemployment and the future in urban Ethiopia, Temple University Press, Philadelphia.

Mattingly, C 2013, 'Moral selves and moral scenes: Narrative experiments in everyday life', Ethnos, vol. 78, no. 3, pp. 301-327, doi.org/10.1080/0014 1844.2012.691523

Morton, H 1996, Becoming Tongan: An ethnography of childhood, University of Hawai'i Press, Honolulu.

Philips, S 2004, 'The organization of ideological diversity in discourse: Modern and neotraditional visions of the Tongan state', American Ethnologist, vol. 31, no. 2, pp. 231-250, doi.org/10.1525/ae.2004.31.2.231

Throop, CJ 2012, 'Moral sentiments', in D Fassin (ed.), A companion to moral anthropology, John Wiley \& Sons, Malden, MA, pp. 150-168, doi.org/ 10.1002/9781118290620.ch9

Trnka, S \& Trundle, C 2017, Competing responsibilities: The ethics and politics of contemporary life, Duke University Press, Durham, NC, doi.org/10.1215/ 9780822373056 
This text is taken from Pacific Youth: Local and Global Futures, edited by Helen Lee, published 2019 by ANU Press, The Australian National University, Canberra, Australia.

doi.org/10.22459/PY.2019.02 